末流此迄广限 $ト$ 此 $又$ 䖪開季本

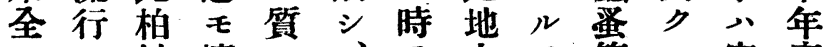
》入标撗 終既系少分同三見群卜氮森 息三統夕ル患フ於ルョヨ篇縣 大三三レモ家シ兵。ナ知シ下

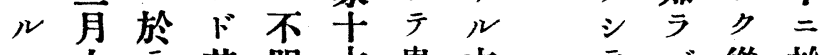
二上其明空患本方灭從於 至旬發感, 名者年寄・ッ只 其疹染點, 發流生屋テ儿 》端手系患見行 入丙其發 ○尹チ統多者セ, ル售疹

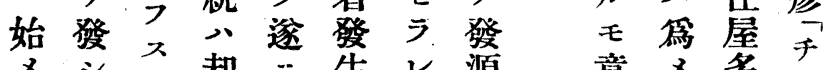

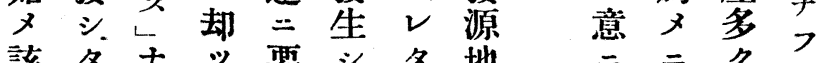
該タナッ，要 シ タ地 $=$ 坏

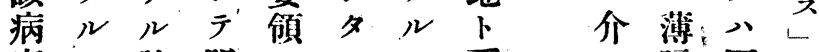
毒モ診明 $\exists レ$ 看七暗四人 , 断暸得ド果做 ズ多面流 何、少 = ザモシ具壁行 處如下シリ他 テ可 $\exists \geqslant=\bar{\jmath} \neq=$ 其 $\neq$ 》’患的。蔓系 侵四著例然延統、入甚圍西

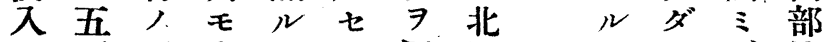
三 兩隔突 $=$ : 同津

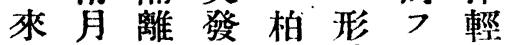
$y=$ サ 村跡 、郡

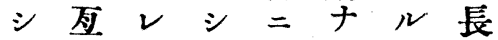
中多夕ガ其 ク十橋 漠最 卜王、手 7 亦 $十$ 及 シ 猖四モ發其確 ビ 天溦月, 䍩證西 知 ル極旬見ル家シ輕 能メ三ズモ相。郡 八六始甚, 互長柏 ズ月 $、$ ダ $=$; 橋村 或 $气$ 整於感村 八分、采於村 貧亏之 困患ヨモ里 $ッ$ シ , 者精, 学親流厅 篇漸查ア 隔染行、雨 二減ル。患同者 醫退二 療核他 馀於 $\exists$ 七病村訪三石 受月，二>局殆

亦 9 八 沐 換 以

浴氮其 $\Rightarrow$ 不、津 好完出 輕 $\checkmark$ 全入地 ズ各方

、少, 岩

其衣外杰 生衣肾川 活服窗, 程 刺空流醫染 度整り域學病 甚当占带士 研 低重蜼帶 衛悘臬地岡觉 思六於尔 想次笑ル

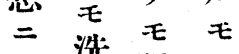
至濯唒, テス榃 シ 、先罗テ 殆卟閉、門 傳 ドナザ此 缺方 シ地 如 、广 冬
原

及大 $大$ ビ 正 昰 其七箱 年 相

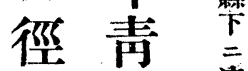
路森梁 就懸䍃

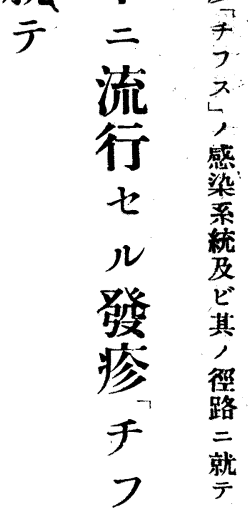<smiles>[Y][Y]</smiles><smiles></smiles> 


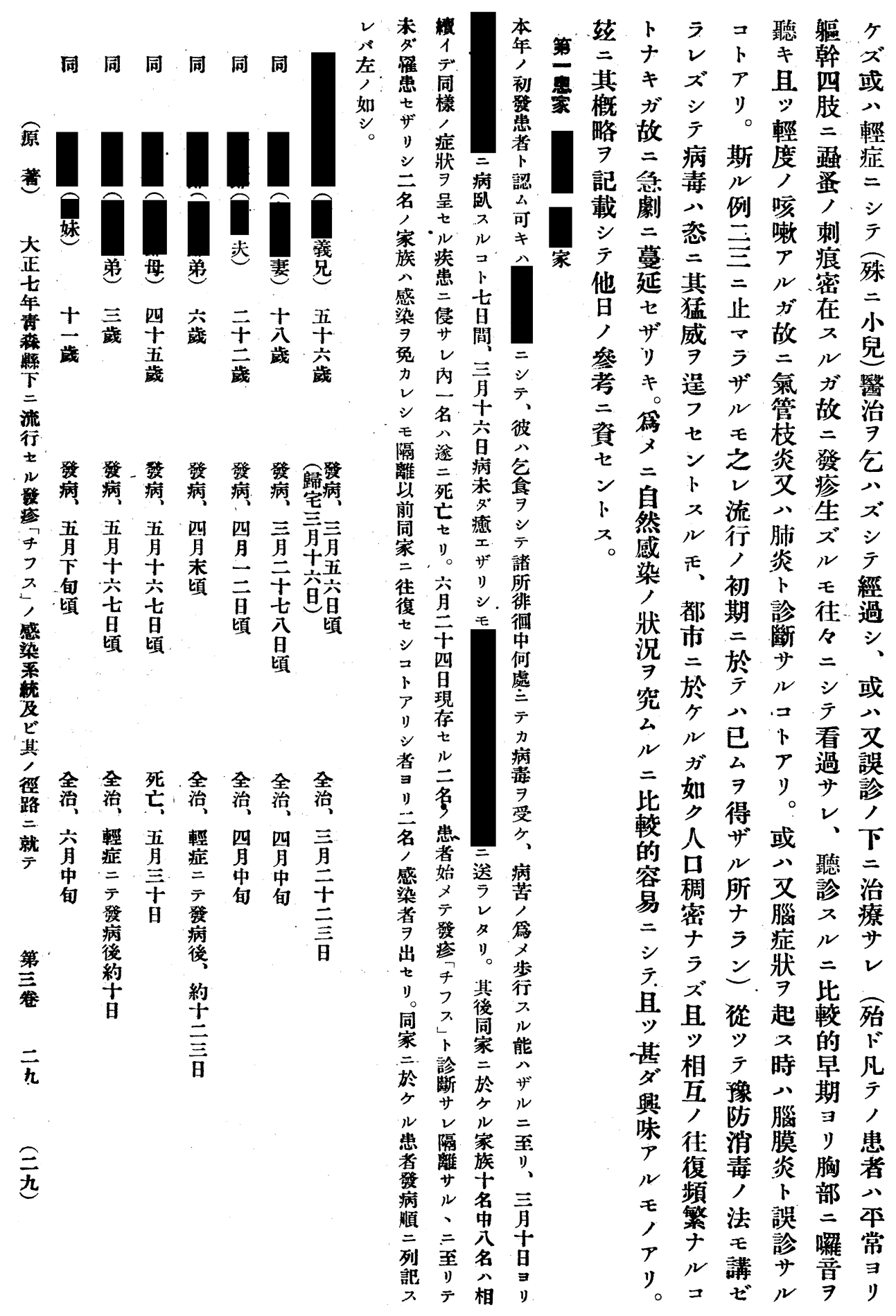


I .

$+$ i.

mi

量

旦

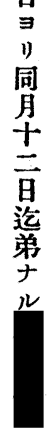

今

亦

日

㮅

師

第

其

四

病

早

着

護

任

當

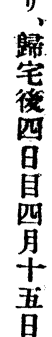

癒全村次，許“前

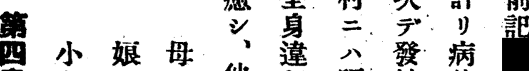

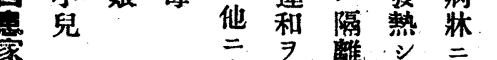
土士三病 挀 病 落 就

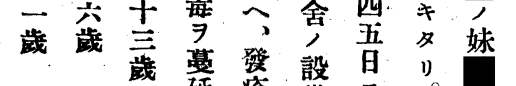
延 痒 储

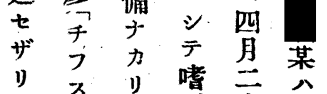

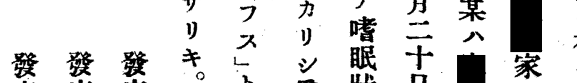

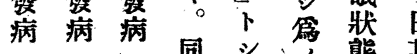

同 シ, 態其發 五五四家取同宿抱病 月月月 於职家陷 第 十吾公於报寻竖少九 日

患レ方 識鼠冒

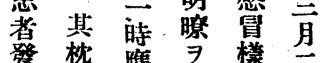

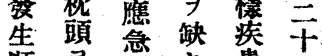

湏 $\exists$ 隔 $\neq$ 患九

䉀 離 囄 時鬲旦

列ザ 病涻

記り舍語 タ テ

ス六當灵儿來

父小八兒少發秋 兒、走他胸菭看

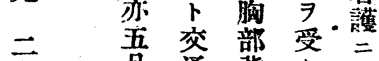

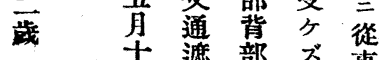

九遮部 ズ 事

早

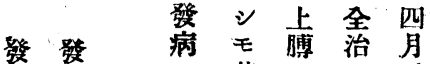

病病专其至七兰

五四全族婜。蹈

月月家公祭宅

線 焦見及 间

線然儿鼠

留居 $1 \stackrel{7}{*}$

艒七及看聂

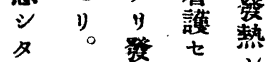

ル、五疹, 彭

モ月年娘晹

何千于

2 四 2 办

普年学吾员

通後診五,

經 交断白疑

過長サ三人

吉 䓀 至 下.

リ寒り。惡 二

テ 發。寒 週

治熱同三間

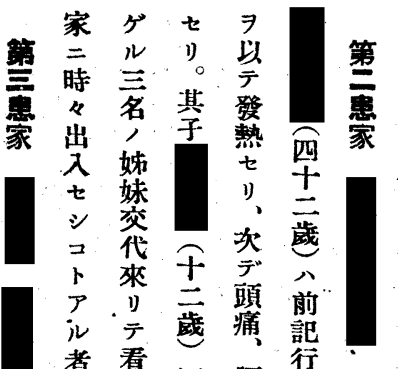

者看四腰行

モ 謢祭痛 病

跑何四四者家

者诰昌痛

》チり竝

第、フ發 熱 全

六 不熱全 宿

患 裳 牃 供 泊

家疾七意

患 $\exists$ 基 $\Rightarrow$ 病 病 發

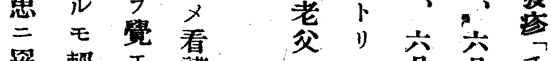

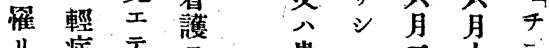

リ 症 テ 瓷

且 病

兴牀

甚 醫 就

族療㯺吉

モ 受 㬵 間

感々莫自

染 ズ笔

始茼 ナ

始週 間

テ人断至

發後 壬

疹治下, 豆

手漓二十

フ染六

ス当等

云 其

殓分、後

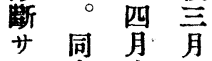

ᄂ家十

夕人六十

引家 日

第族潮旦

三父歩》

四子行感

吾名得龺

虫名、待氣

患八

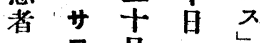

叶,

接 =

スシ 染

ルデ番

機

较 夹

䡆泰其

少着全全雚

遂護治路

感 $゙$ 月

染八十十

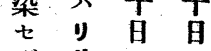

ザサ

リ

リ、第

第
厺
三

家

族

八

荎

起

卧

领

台、態留

木他 =

葛三恢恐

西嫁復寒
系

ビ

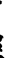
(n) 


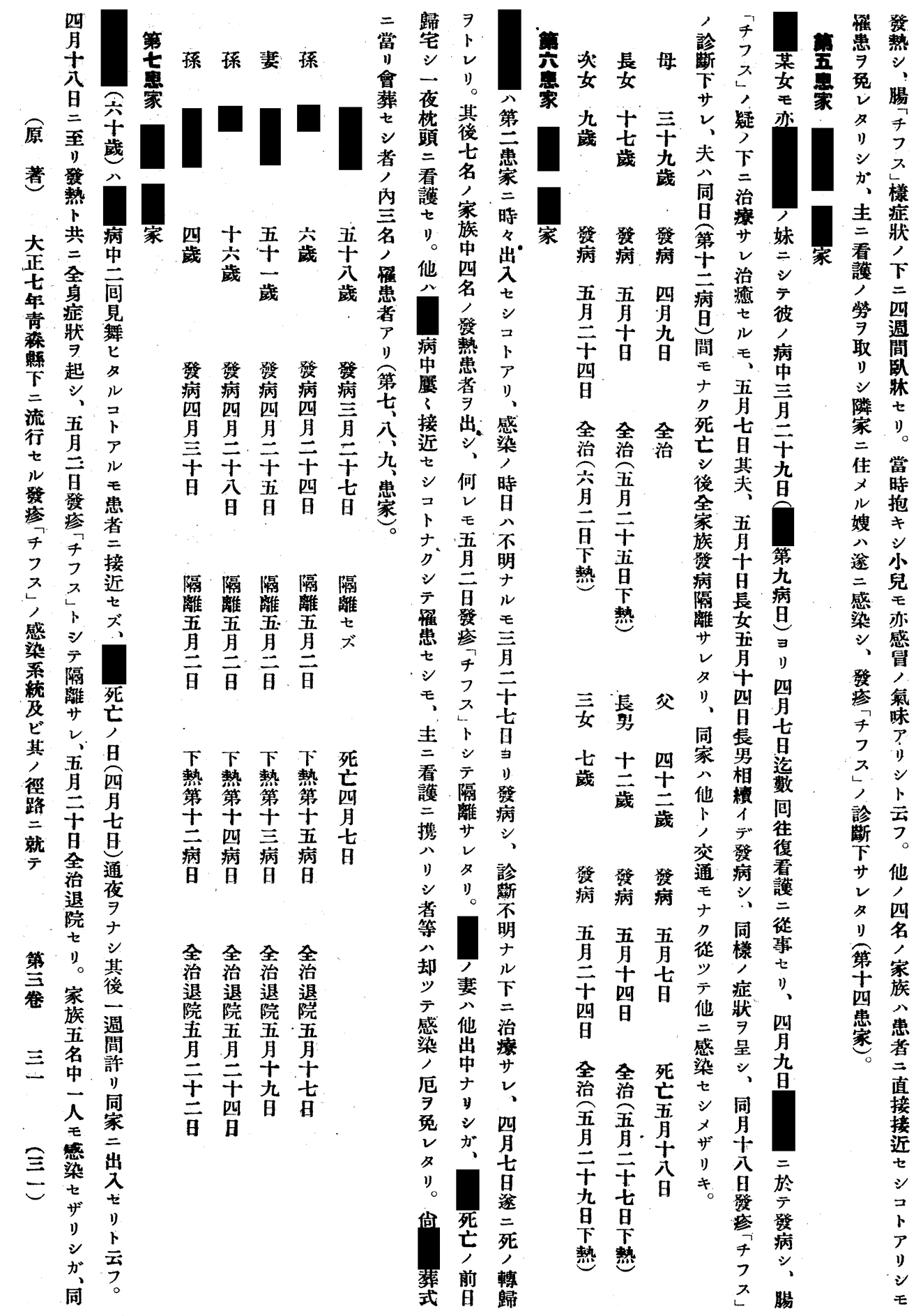




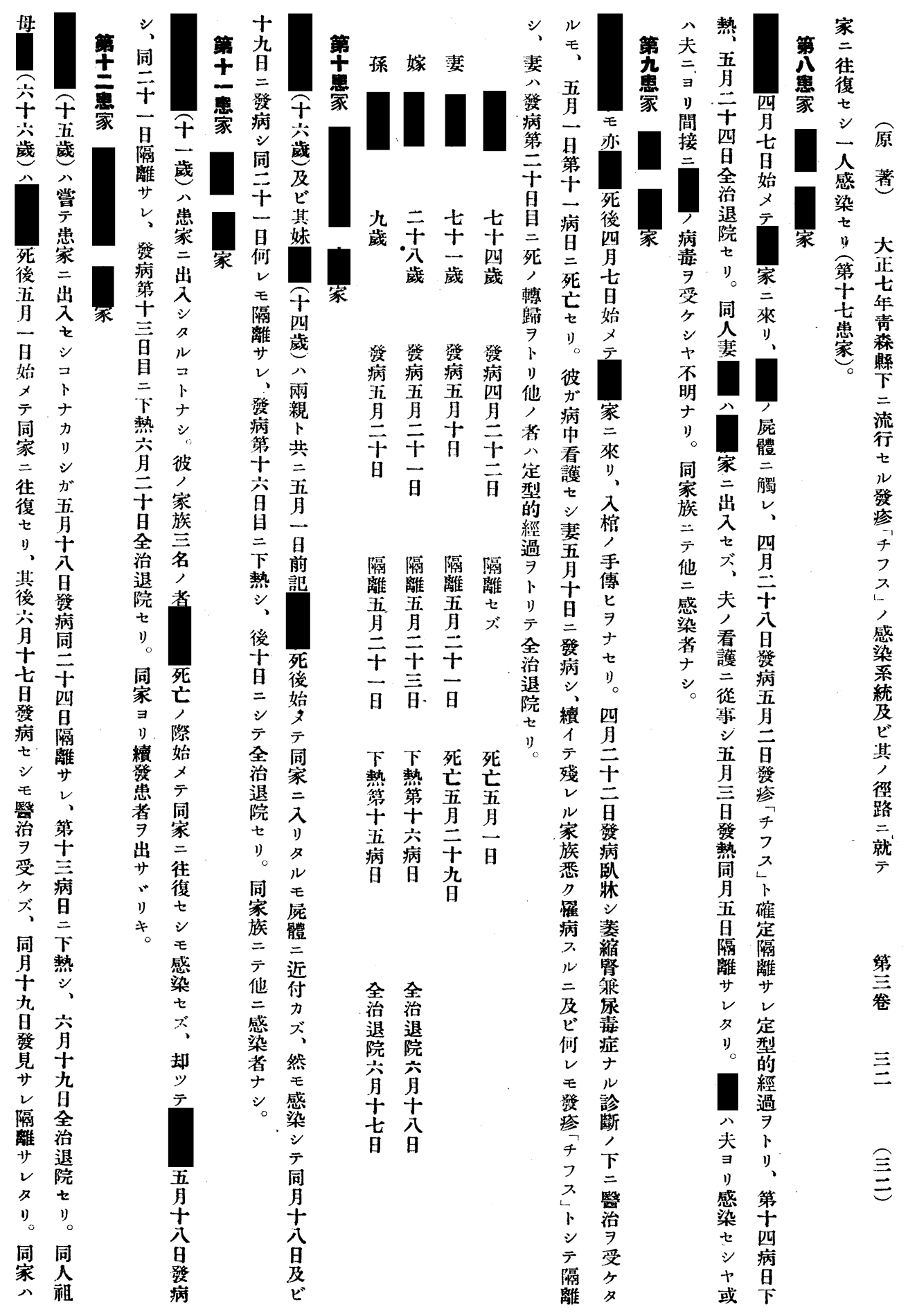




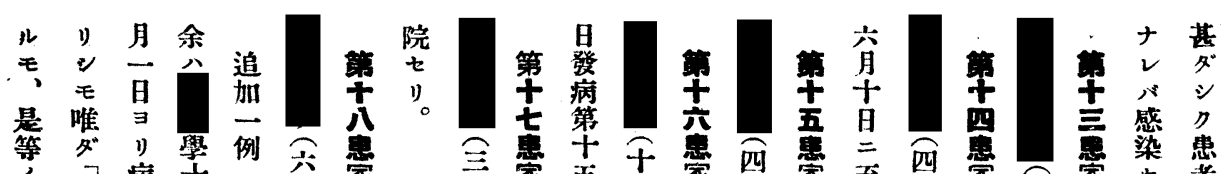

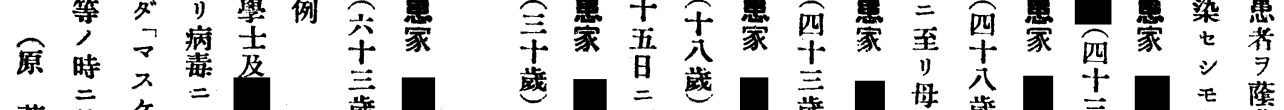
著 於乞 公 㼥 テ角絕技手苸 大篦意三下第 大防厅 接共 七沙力触 年毒りさセ 五 青 三 對 カ

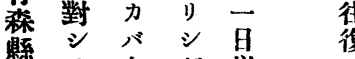
下 等

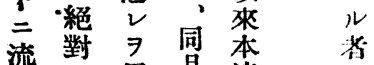
行三用等流 七過 $ヒ+$ 行 ル失卆地 發ナ シ 早 答》患出出 チ艺者中偶 ス, 接然病 上卜 接患毒 感信染者極 染系而器

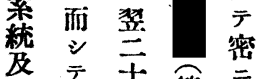
ビ 六 古第 接 其六再士触 徑示同患 タ 路宍患家 二百者二ド䔶 就夕荍

刻接會、等 極沙常、 示 察 豫 第 暧 千防 秦隐 第 。堽 寒 一此 $=\exists$ 患際 $=$ 三覺家他 注 其到瑔 夜り防意 體 三 消 ラ 三温名毒 ザ 三三患法 キ 八者 溃 度接憾 $\begin{array}{lll}\text { 上丨 } & \text { 年タ } & \text { 六 }\end{array}$ 근

筧

嵒

離

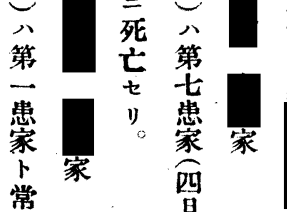

常

t

八

今

$\overrightarrow{\mathrm{B}}$

全

退

v
往

復

り

月

豆

病

第

患

蜜

於

於

ル

最

終

患

八

鼡

量

四

嵒

踤

サ

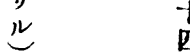

其

後

嵒

月

五

㜔

離

往

得
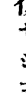

$=$

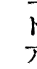

r

E

患

者

接

近

亲

染

奛

四

㫤

病

同

艺

同

月

F

r

全

退

$=$

t

早

隔

サ

ㅊ.

月
是

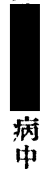

同

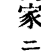

往

復<smiles>C1CCCC1</smiles>
共八 二 第

發 四

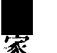

疹 虫

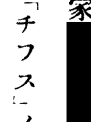

馀

器

'

隔

離病

レ ガ

名病

1) 中

月

㝵

是

病

窈

$+$

旦

嵒

離

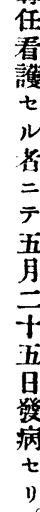

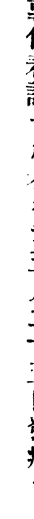

其 身

点

九 1

蔵接

办 閶

五 係

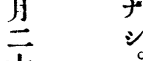

t

發

病
来 蔽

發。

見 ル

$\checkmark$ 風

經り

家過 向

發家

患 $=$

者 於

ナク

$\neq$ ル

月. $\rightarrow$ 初

九保發

是七患

見 プ。者

見

サ 踓

同脑

人後

学

族

t

名

中

在

程

テ

健

建

敦

$\exists$

受

ザ

N

者

名

モ

1)

ม

罃 
二本觸通劇发角令身的以

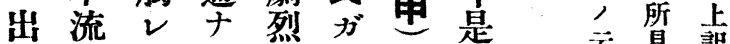

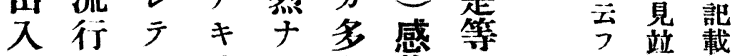
シ。閁時儿人染, 所三 义於接分流數踓患症經所 八モ接感行染路家 牀過患 忠之觸了来生就 ビ察登萣 考々感災 死全シ免常ナ山二考采入其

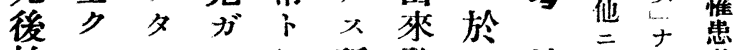
始一ル上所發尔按感心著 又致例得、疹儿染誰四 ラシモ ル而例手自 接䍜㯪コモュテ然 近患 3 患心゙威 シ者記 心者木之染 或大載既, 家宿接狀 “多亏, 族貧觸況 又數 2 事同食威二 自心 實居部染就 己患所于者落, ₹ 卜者ナり文或最觀 患 $=y$, 公察

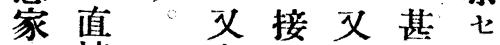
卜接患近生必的 八接者者活、三所 直觸占二狀 $\neq$ 皮 接二直感態傅述 何依接染, 染心 等y接 问觸・良三

關其飞必

係 他 子, 儿上戰塽 力少毛患場隘

》數 其家等不

谷衣上潔

忠 類住於

他著心居厂儿

人洗隣好非

人接嚁接 衛

媒近物セデ生

介七儿愽的

ニ ザ 排モ坐住

俄泄相学居

y物互

厂患等, 推下

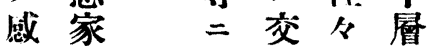

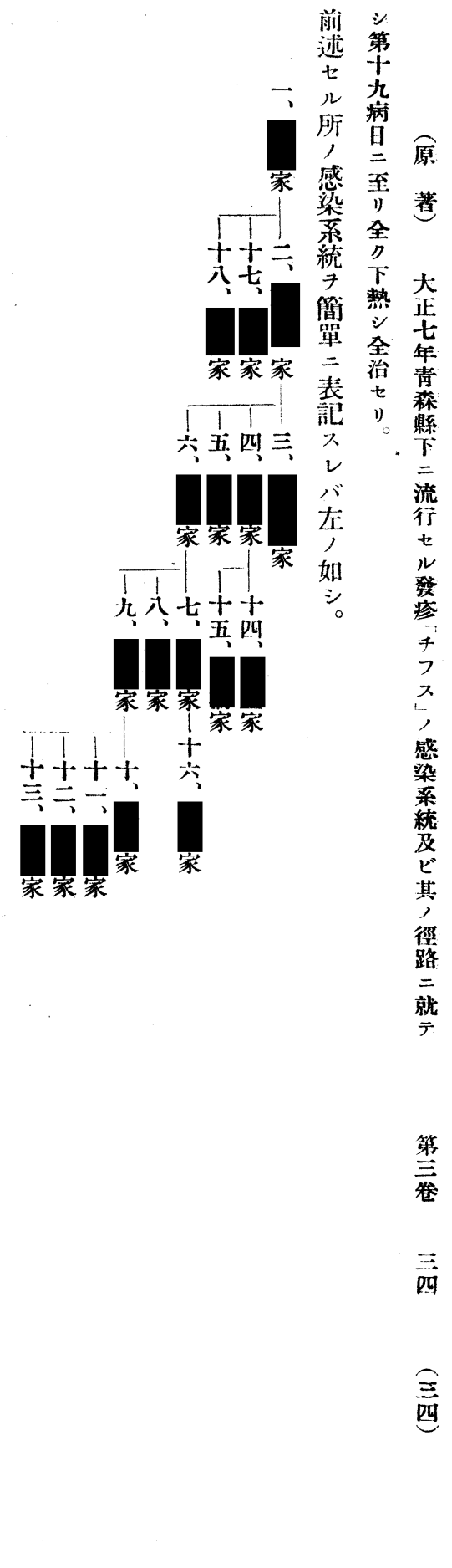


飛是心テサ二定斯と患り及フ比者染儿而染

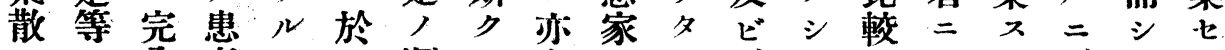

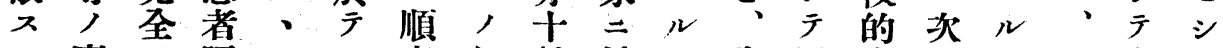
几 事 $\exists$ 隔二八序如數於日全羅少 $1=$ 何患者 原コ實期離及全

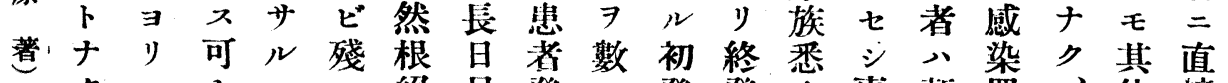

ク、シカ、絕月發》。發發名事暂䍜、住接而

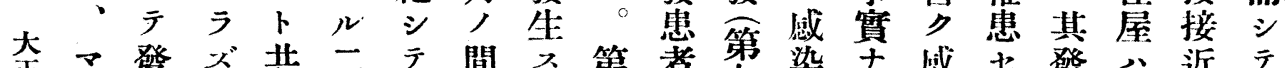

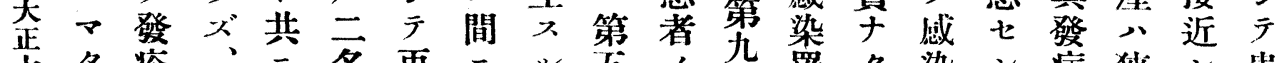

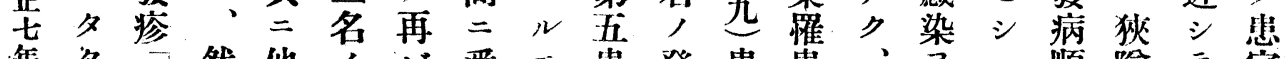

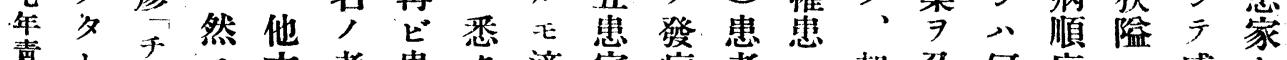

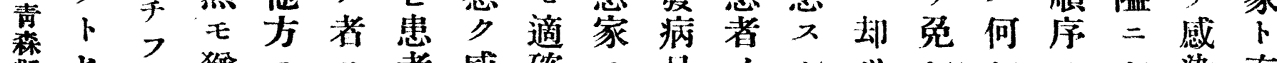

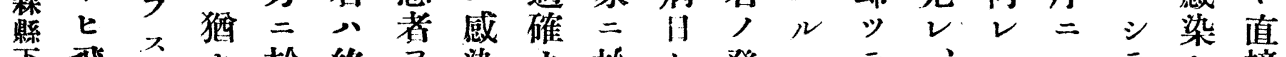
舀

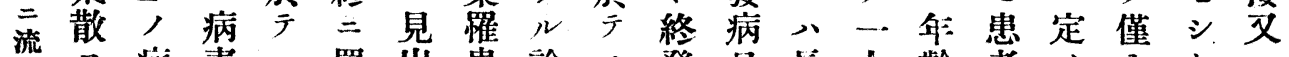

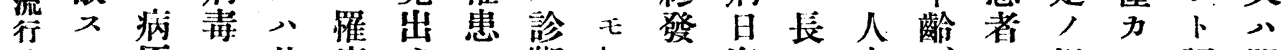

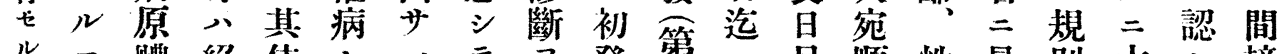

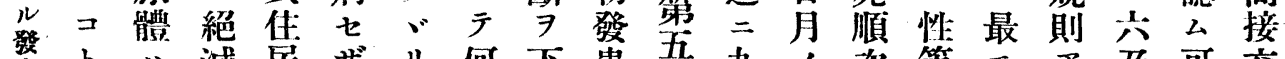

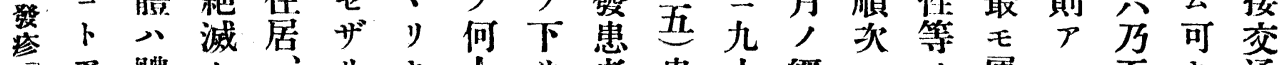
子ア體七活

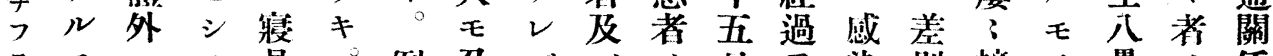
즈 モ具。例免ズビ,

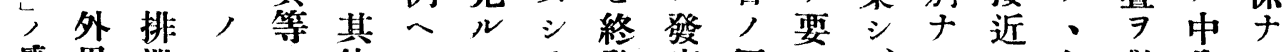
感界泄、今他バコテ發病經入、”七如敷全》 染三七如鬼人第卜豫第11過皮病何 シ 另家》 緮對

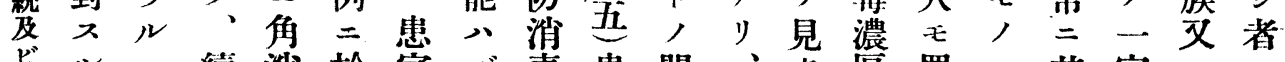

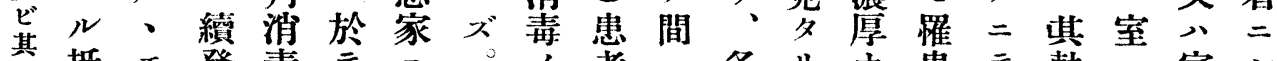

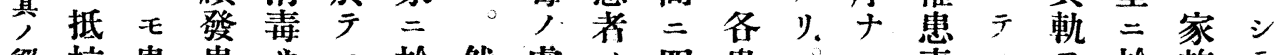
茳抗患患サモ於然處, 四患。儿素看 路力者者ン總亏少置發十者例二貿看一篗一威 就”,

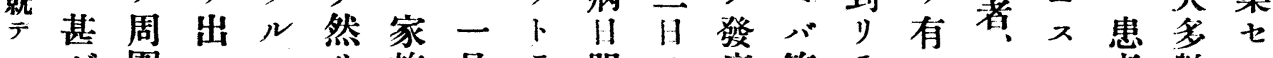

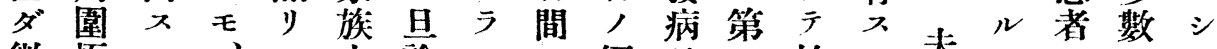

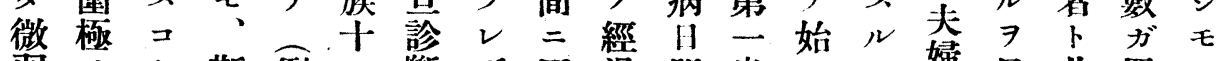

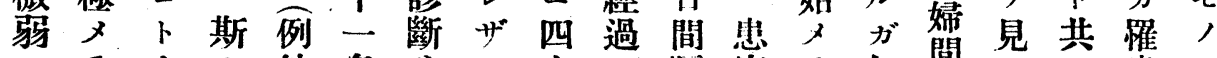

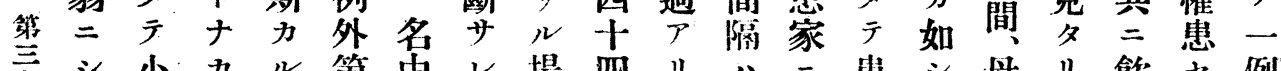
共

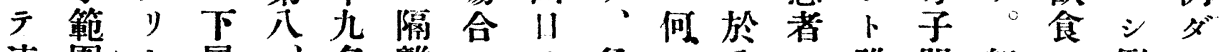

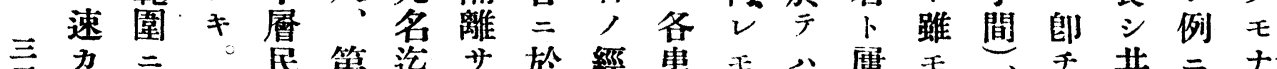

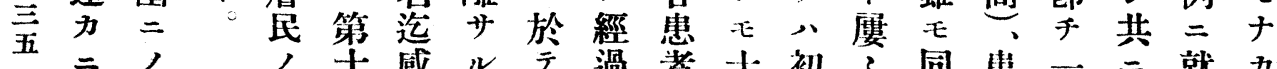

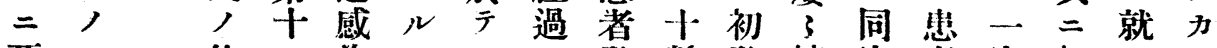
死三住一染 $、$ 八發數發按家者家起

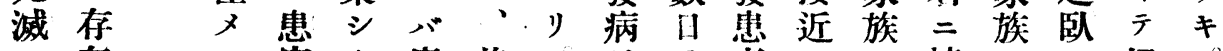

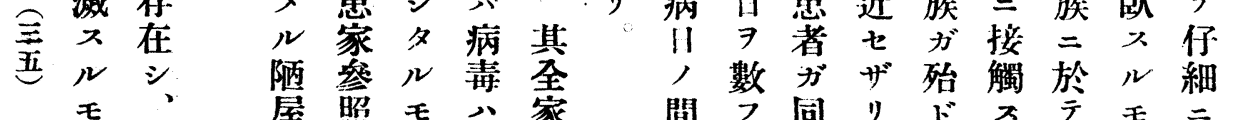
モ 屋照モ、家間 フ同りドステモニ 決隔。家三時儿初直觀 ナシ 消而隔患八 ルテ 毒 $シ$ 離家一之票入气同機㭧感 
基猩急一推豆發七乞態シ觸其發何り二可

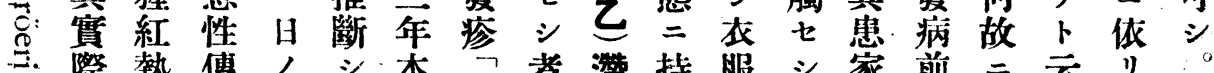

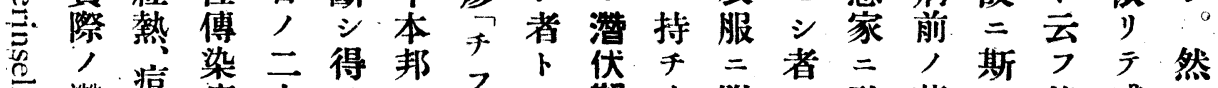

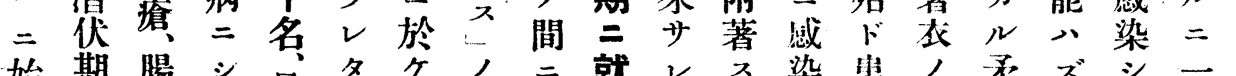

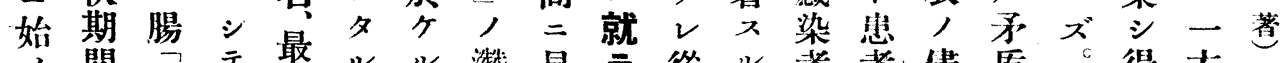

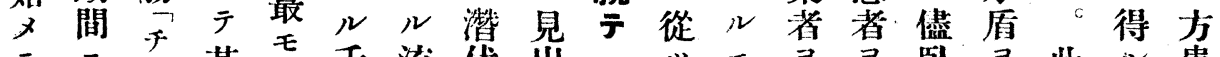

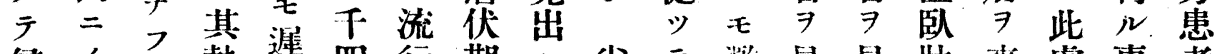

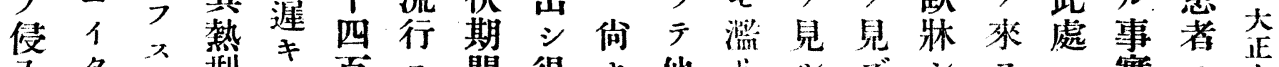

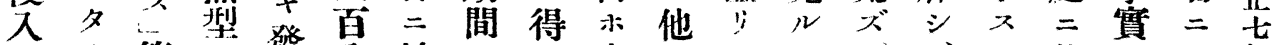

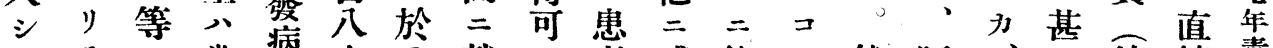

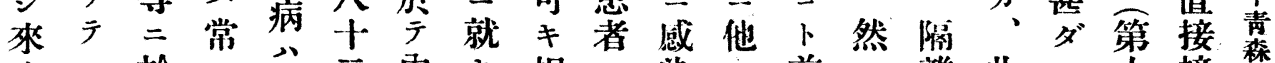

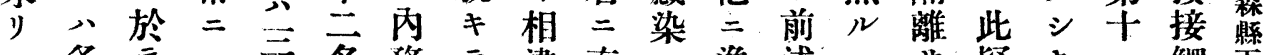

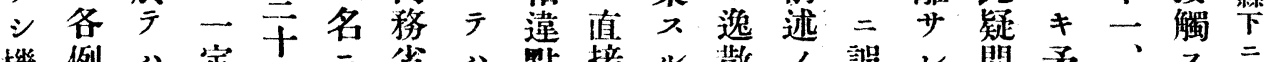

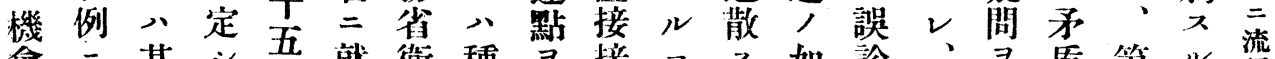
會三其 シ吾就衛種 $\exists$ 接 コ入如診、 7 盾第

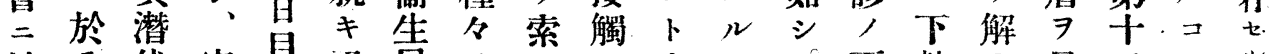

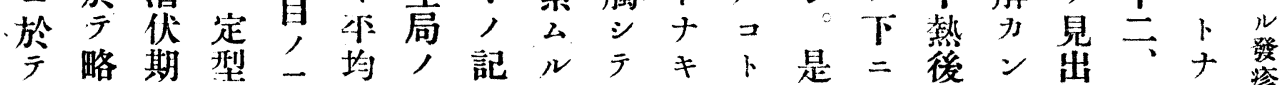
正? 間的台濳調誡

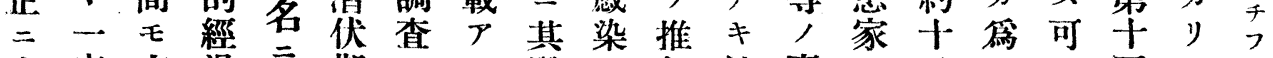
十定亦過三期七 $、$ 潛七知性事三日

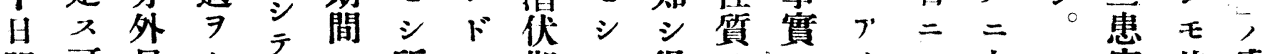

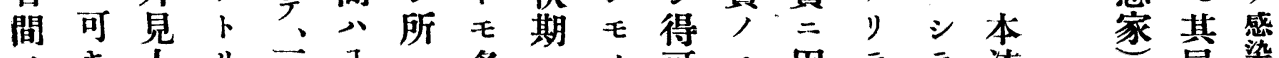

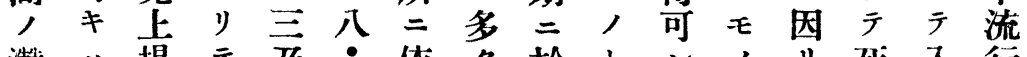

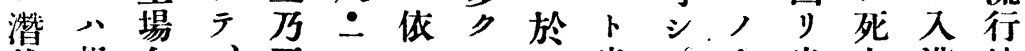
焚想合、至三人, 患。十患它浴地 期像二明入高心゙學著著之心著入入方

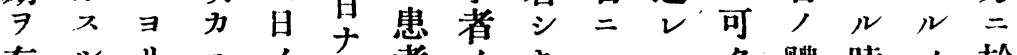
有ルリ二, 者, 者二只體時八於

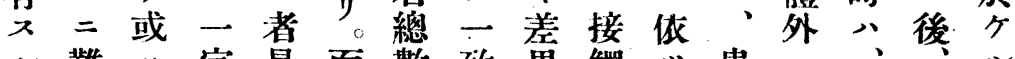
難八定最而數致異觸 患二、待

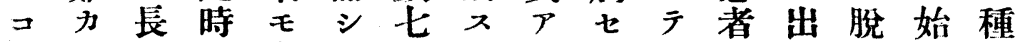
卜ラ短日多テ下ルルズ前隔デ衣メタ ヨズア, ク其八所

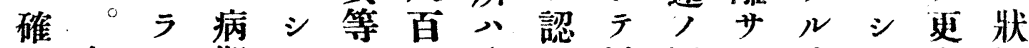

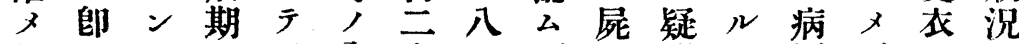

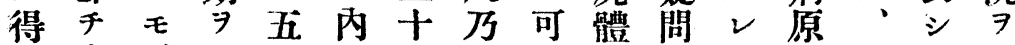
多麻: 別十最八至之又心咀其示調 》疹之千早名十“分解其心㡾退查 之向 2 得 \% 只云他決病主體院

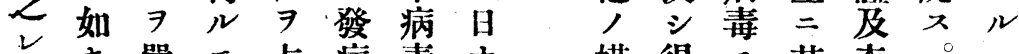

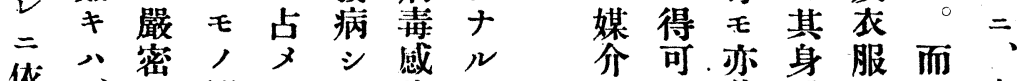
低 : 密例夕夕染ガ

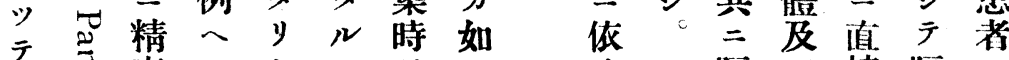

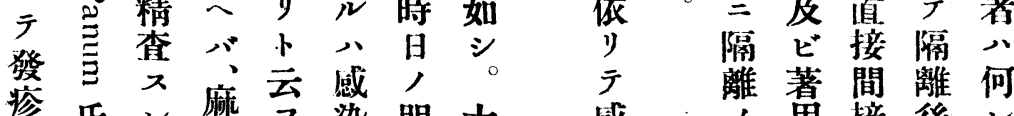
疹氏

虔染

$\exists$ 體 䟽

y $=$ 及 觀 接 筫 ᄂ $\pi$ 八゙徨 該 コ路 病卜就 原 $=\bar{T}$

體 依

多”

界 或第

永芼

於又

辰屍

必體亲

ズ $=$

シ 接

モ 觸

抵 $七 \supseteqq$

抗 三 意

力者

微,

弱 媒

+ 介 


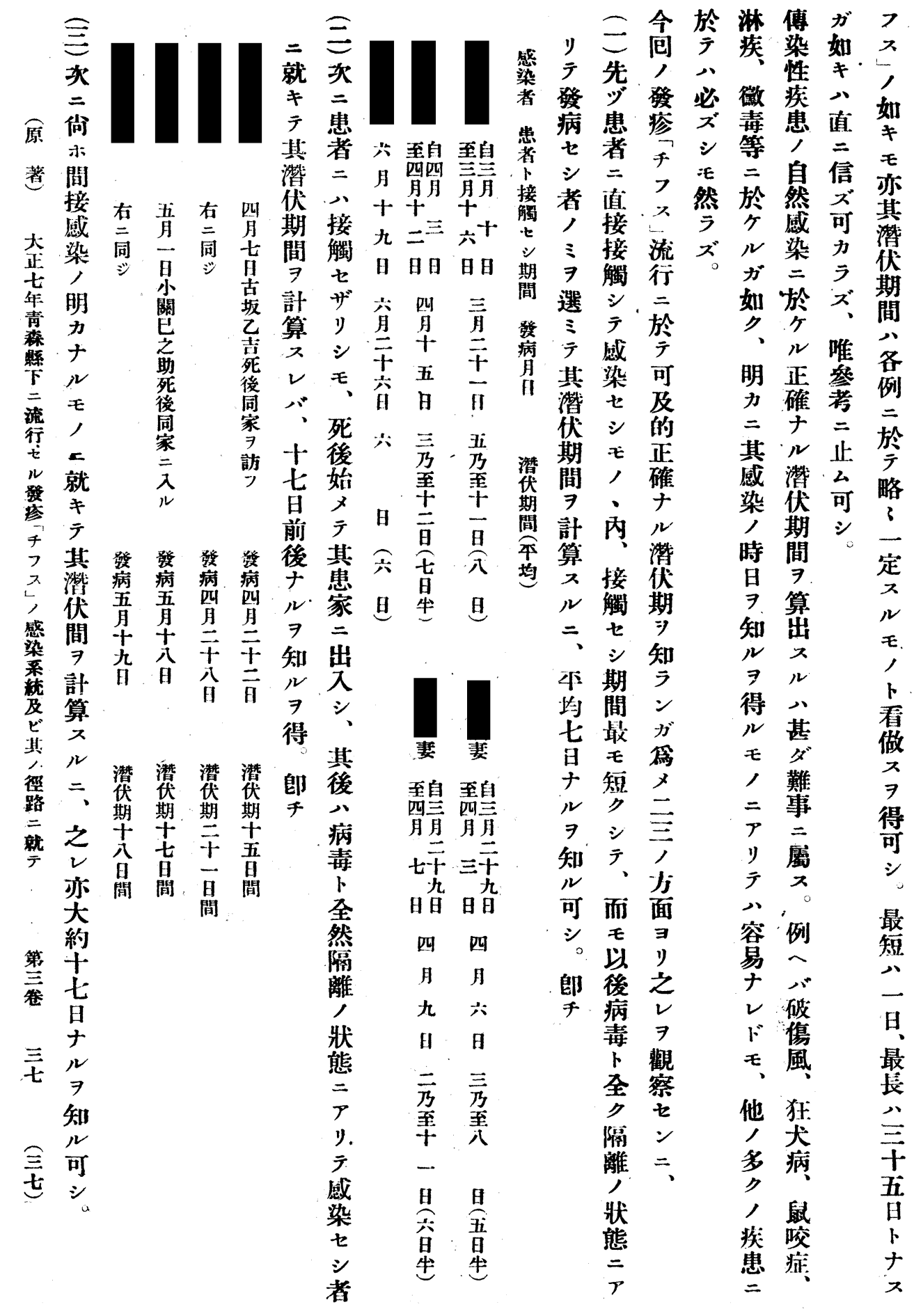


他得濑 $コ$ 發ル

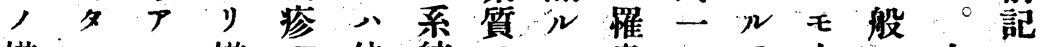
媒 $ル$ 媒于他統 7 二患 7 十 介事 $尹$ 介

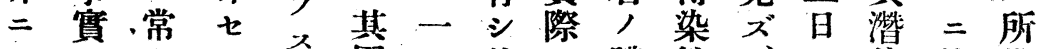

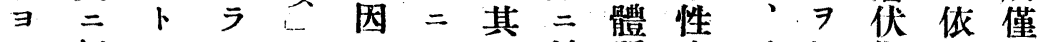

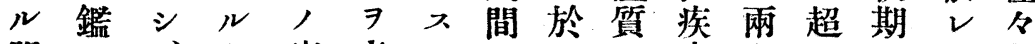

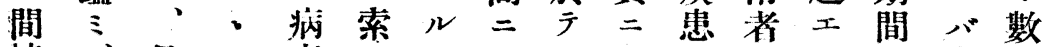

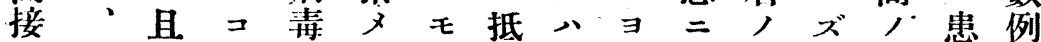

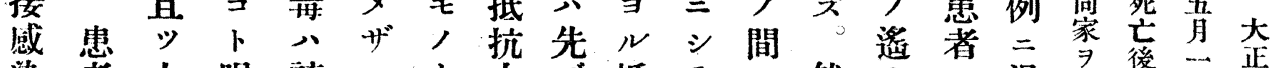

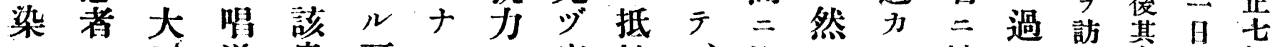
八二正道患可 $ル$, 病抗、格 $=$ 接ギ 接三七者乃 ガ强毒少而段二短觸ザ、族關畐 患觸年 者 シ 東 ル排 ズ二二接强其差者 7 テド

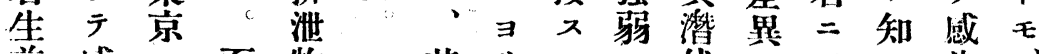

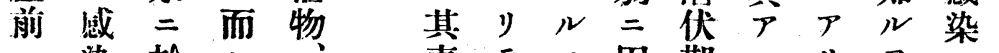

二染 於 三 於入ケ厅 尿 テNル多便 病者流多 毒, 行, 喀 马 多 時該 痰 昨 $\Rightarrow$ 二病 人 八口㭧呼 儿、蓋者氣

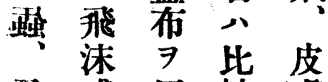
蛋感用較膚 等 染 $七$ 的落 人二タ早屑 逸 $コ$ 期 等 政ル 後 $\exists=$ シ $卜$ 小

テ認䂑氣り

么 師管 テ

適 ル、枝散 度 7 看 加亂 得護答 シ 淄可㓎兒或 卜 濕一職牀哿 氣方務 $习$ 生 卜死感有 䖪 有分染者、虽 入咸數多番 健染減少等 康八核二

毒テモ因期ルリリヨ七最發發绗

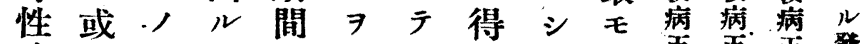
時八 $、$ 力 認八者正五五發

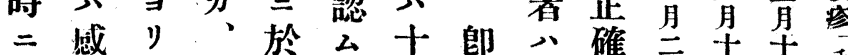
八染順或テル七千、示入八分 高 $三$ 次八前 7 八前患近公日早 ”或 二又表得日者者手

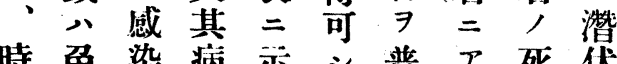
時免染原示意通少後期

八ル、體, 低、年, 如 シ ガ 龄 毒 ク 卜 如、性

看性, 明 做傾、高力

不向體低二

能 買二少 八ル等歸多 ズ $\exists=$ 因 見 $\exists$ 不

此ルルル二 故能差 二 樣 二小異卜=

濳 ズ $尹$ 直 區 伏 認二別 期 $\checkmark x$ 想 間 タ. $x$ 像 得 二其、七ル 圭病何今 短原人心、 笔 $モ$ 可之 樣明感 シ レ $>$ 染。蓋
广始日市十十椘

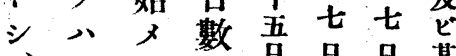
其均接算間間間 最七近出 短 日 棌 キ 間 又得 E $=$ 分 人過他 ₹ モギ，條 猴 ズ媒件 头留, 十且 $=下$ 五因二 日其》 以最テル 丙，長威王 二期染, 發間七、 病, 七比者 シ , $\exists$ 選 モ 7 V. , 卜 E 夕
路 熟 篹 亲 $\widehat{\underline{\lambda}}$ 
七六死五四三三”三

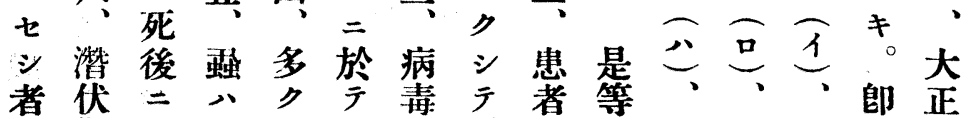

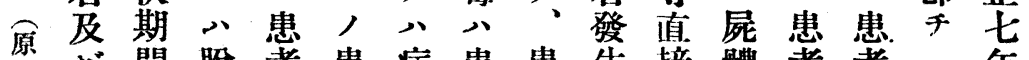
著其八間衣者患病患患生接體都者 等二七衣 大著二シ服比屍離接モ間近中近

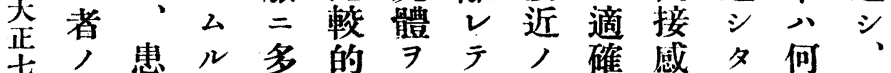
集媒者 ガ數早雗存程ナ染儿等又 素介二霖群期 $v$ 在度儿二第, 八

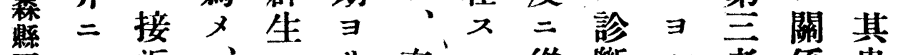

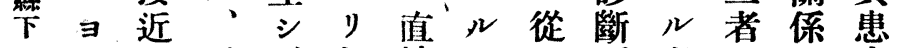
洮》三䖵、氣接

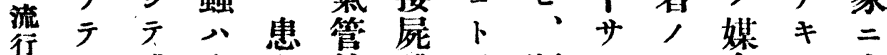
七威威逸者枝體殆順 染染散生加二F次ズ八二、入 管七七存答觸ナニシ シ シテ中兒レク長テ名り後テ ᄀモモ健八, ザ、早、氐始威 ス, , 康更症 2 患月豫該威 , 二 =者衣狀モ者, 防病染テ七 感於於 $=$ 又, 隔間消患七其

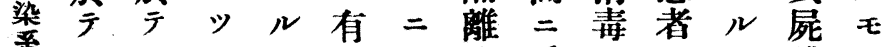

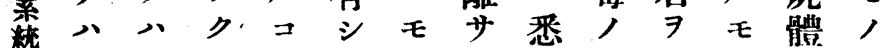
策、本コト、他少道見, 萁普均上小多人、威講基。接 其通七想キ劣媒時染ゼり近 徑十日像 7 , 病入ラ・キ 路七。サ以咳二毒ルレ゙ 就尣二ル示濑 $\exists$ モ 白三。從之り共見ル $\exists \vee \%$ 威 $三$ 時 數屍 厅二染隔り

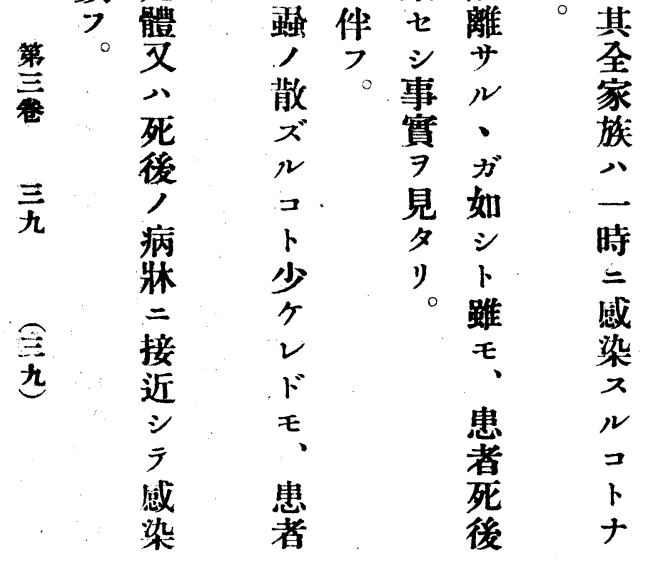

知 斯 者

可, 著

シ 如衣

其

威 移

染 住

, 寄

仕 生

西摘㝑

輕 二

郡 要 三 其

柏樣病

村学

N

モ媒

, 介

卜

假 ル

定 7

有

七

シ

發

疹

7

7

x

$=$

染染答

七

:

モ

岛

染间

系別

統

不

明

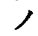

モ

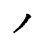

例

千
入考

$\checkmark$ -

バ 得

濳、シ

伏

期

間

$=$

亦

長

短

$\overrightarrow{\text { 楼 }}$

$\Rightarrow$

得

N

ב

卜

故

無

キ

$=$

非

ザ
其 可 


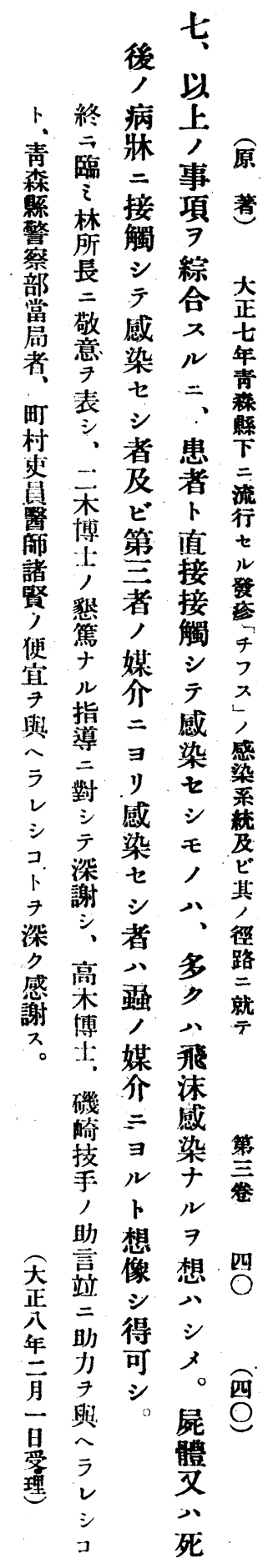


2) The maximum- and minimum-resistance diminishes in infected horses almost equally, so that the amplitude of the resistance (Resistenzbreite) remained unaltered from that in normal horses. The author therefore, comes to the conclusion that the red blood-corpuscles of the infected horses must be subject to an uniform diminution of resistance.

(T. Mitamusa)

\section{On the Mode of Infection and the Period of Incubation in Typhus; a study of an epidemic in a village of Aomori-Prefecture.}

By

\section{Dr. Masuemon Okada.}

(From the Institute for Infectious Diseases of the Imperial University, Tokyo.)

I) The author made a thorough study of one of the epidemics of typhus, which occurred in Aomori-Prefecture in 1918. In this epidemic there were 48 cases in eighteen families. In none of these cases was the origin of infection obscure. The infection occurred in only three ways: (a) by coming near the patient or visiting the patient's family, or (b) by approaching the corpse of a typhus case, or (c) by touching things or persons, which had formerly come in contact with the patient or the corpse. In other words there was not a single case of typhus, which had not some relation with a former case of typhus, directly or indirectly.

2) When a patient in a family is not isolated in proper time and manner and the house is not sufficiently disinfected it usually happens that most of the other members of the family are infected with typhus, not simultaneously, but one after another in a more or less long period of time.

3) The causative agent of typhus does not usually remain infectious, when separated for some time from the patient. But the author has strong 
evidence, that the disease may be transmitted to man by means of something or somebody, free from typhus, carrying the virus.

4) From a relatively. early stage of the disease, most of the patients show some signs of bronchitis and complain of cough.

5) Lice are abundantly present in the clothes of the patient. It is believed that' while the patient is living, these lice do not so easily detach themselves from their host, but on the contrary, very rapidly leave, when the patient is dead, and attack another, healthy, person.

6) It is a very interesting fact that the time of incubation distinctly varies according to the mode of infection. Those who are infected by close contact with the patient, show an incubation period of 7 days on an average. Those infected by coming near the corpse of a typhus case or by other indirect means, show a relatively long time of incubation, i. e. 17-18 days on an average. The author therefore considers, that the infection occurs in the former case very often by the socalled droplet infection and in the latter case mostly by means of the louse.

(T. Mitamura).

\section{A Statistical Study on the Fever and Stool in Typhoid.}

\section{By Dr. Tsunejiro Nishi.}

The author made a statistical study of typhoid cases, treated in the Komagome Municipal Hospital, Tokyo. Out of 222 cases the typical and the remitting type of fever were found in almost the same number. From the prognostic viewpoint those with non-remitting fever appear to be severer than the other.

Concerning the stools of 313 typhoid cases $74 \%$ of cases had more or less marked constipation and the remaining complain usually. of diarrhoea. In the latter cases the illness is often severer and the intestinal haemorrhage is more frequent in these. 